\title{
Nutritional and hormonal control of skeletal-muscle cell growth and differentiation
}

\author{
John M. Brameld*, Peter J. Buttery, Janet M. Dawson and Jane M. M. Harper \\ Department of Applied Biochemistry and Food Science, University of Nottingham, Sutton Bonnington Campus, \\ Loughborough, Leics. LE12 5RD, UK
}

\section{Skeletal muscle growth and differentiation}

\section{Processes involved}

The growth of muscle involves increases in both cell number (hyperplasia) and cell size (hypertrophy). Hyperplasia involves the mononucleate muscle precursor cells (myoblasts), which subsequently align and fuse (differentiate) to form the multinucleate muscle fibres. This is the stage at which increases in cell size take place (Fig. 1). The present review will concentrate on the control of myoblast proliferation and differentiation, but will also mention the control of muscle fibre size. The total number of fibres in a muscle appears to be fixed at, or shortly after birth, with postnatal growth of muscle being entirely due to elongation and widening of the existing muscle fibres. However, this does not imply that the muscle precursor cells cease to grow at this stage, as the DNA content continues to increase until the animal approaches its mature size. Extra nuclei are recruited into muscle fibres from mononucleate myogenic cells known as satellite cells, which are enclosed beneath the basement membrane of the muscle fibres (see Harper \& Buttery, 1992). Muscle cell differentiation, the process whereby mononucleate myoblasts become postmitotic and fuse into multinucleate myotubes, therefore takes place during the late gestation and neonatal periods, with differentiation in the neonatal period involving the fusion of satellite cells with the existing muscle fibres. The processes involved in muscle cell proliferation and differentiation have been mainly studied in a variety of continuous muscle cell lines, but recent work has employed normal primary cells from several species, including domestic animals (for review, see Dodson et al. 1996).

\section{Transcription factors involved}

Considerable work has been carried out recently on the role of muscle-specific transcription factors in the control of muscle cell determination and differentiation. These transcription factors consist of a family of nuclear proteins termed the MyoD family and comprise MyoD, Myf-5, myogenin and MRF4 (also known as Myf-6 or herculin). A number of reviews of this area have appeared recently (Ivarie, 1993; Weintraub, 1993; Olson \& Klein, 1994; Ludolph \& Konieczny, 1995; Rawls \& Olson, 1997) and so only a brief discussion will be included here. The MyoD family share approximately $80 \%$ amino acid sequence homology within a basic helix-loop-helix motif that mediates dimerization and DNA binding. They function as activators of muscle-specific gene transcription and, hence, forced expression of any one of them can convert fibroblasts to muscle cells. In general, cultured muscle cells express MyoD or Myf-5 mRNA (or both) during proliferation and differentiation. Myogenin mRNA is expressed on fusion of muscle cells and declines thereafter, whereas MRF4 mRNA is only expressed several days after differentiation (Montarras et al. 1991; Smith et al. 1994). Due to these different patterns of expression, it has been proposed that MyoD and/or Myf-5 expression is involved in the determination of muscle cell lineage (Fig. 1), and possibly differentiation, with the two having very similar functions. Gene knockout studies in mice have shown that null mutations of either gene have no effect, whereas null mutations of both genes results in mice which are born alive but immobile, due to a complete lack of skeletal muscle, and which die soon after birth (Rudnicki et al. 1993). Myogenin, on the other hand, appears to play a key role in the processes of differentiation and formation of muscle fibres (Fig. 1). Null mutations of the myogenin gene in mice also results in perinatal death, with muscle regions comprising mainly of myoblasts and very few myofibres (for review, see Olson \& Klein, 1994). It has been proposed that MRF4 either plays the same role as myogenin, but postnatally, or that it functions downstream of myogenin in the muscle differentiation pathway (Fig. 1). Null mutations for MRF4 show no deficiencies in skeletal muscle, but a threefold increase in myogenin expression, which would seem to indicate that myogenin can compensate for a lack of MRF4.

\footnotetext{
Abbreviations: DFMO, $\alpha$-difluoromethylornithine; EGF, epidermal growth factor; FGF, frbroblast growth factor; GDF-8, growth and differentiation factor-8; GH, growth hormone; IGF, insulin-like growth factor; IGF-1R, IGF type-1 receptor; IGFBP, IGF-binding protein; TGF, transforming growth factor.
}

*Corresponding author: Dr J. M. Brameld, fax +44 (0)115951 6168 


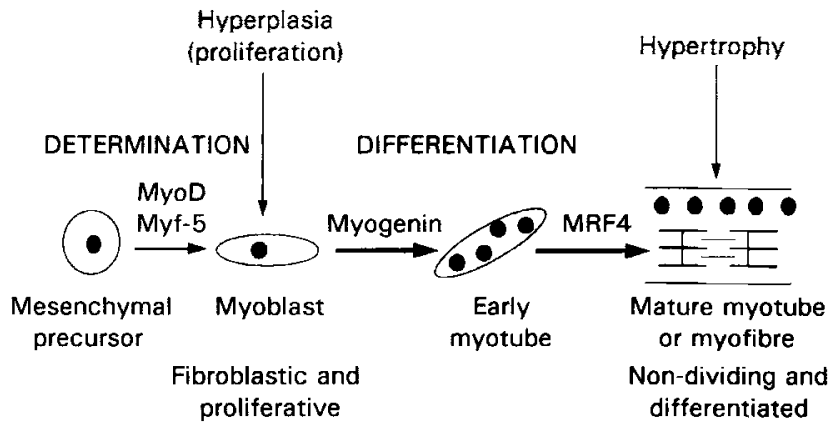

Fig. 1. Skeletal muscle cell growth and development, showing the changes in cell-type, the MyoD family of muscle-specific transcription factors (MyoD, Myf-5, myogenin and MRF4) involved in controlling these processes and the stages at which effects on muscle cell hyperplasia and hypertrophy take place.

A number of other nuclear transcription factors or cellular oncogenes have also been implicated in muscle cell development, including Myc, Fos, Jun and Ski, but these are beyond the scope of the present paper and are reviewed elsewhere (Hesketh \& Whitelaw, 1992).

\section{Cell culture studies}

\section{Effects of growth factors and hormones on myoblast proliferation and differentiation}

A number of growth factors and also metabolic hormones are involved in controlling the processes of muscle cell proliferation and differentiation (Table 1), with all the studies employing in vitro cell-culture techniques. The insulin-like growth factors (IGF)-I and -II have been shown to stimulate both proliferation and differentiation of a variety of muscle cell lines and primary muscle cells, with the effects thought to be predominantly via binding to the IGF type-1 receptor (IGF-1R), which is structurally very similar to the insulin receptor (Duclos et al. 1991). This is demonstrated by the finding that the addition of genistein, an inhibitor of protein-tyrosine kinase (EC 2.7.1.112), severely inhibits myotube formation and myogenin gene transcription (Hashimoto et al. 1995). The mechanism for the positive effects of the IGF on muscle differentiation appears to be via their stimulatory effects on myogenin gene expression (Florini et al. 1991a), with an associated decrease in Myf-5 gene expression during IGF-induced differentiation also being found (Mangiacapra et al. 1992). The stimulatory effects of IGF-I on differentiation, as indicated by increases in intracellular creatine kinase $(E C$ 2.7.3.2) activity, have been shown to be more potent than those of IGF-II, in terms of the concentration needed to elicit a half-maximal response, both in cultured fetal sheep myoblasts (Blachowski et al. 1994b), and also in the L6 cell line (Florini et al. 1986). However, IGF-II results in a much more extensive degree of differentiation, since greater increases in creatine kinase activity are observed with IGFII than with IGF-I (Ewton et al. 1994). This is proposed to be due to the greater mitogenic actions of IGF-I, because inhibition of the mitogenic effects of IGF-I by inclusion of cytosine arabinoside, results in similar maximal increases in creatine kinase activity to those elicited by IGF-II (Ewton et al. 1994). The effects of IGF on proliferation and

Table 1. In vitro effects of various growth factors and hormones on muscle precursor cell proliferation and differentiation and on differentiated muscle-cell protein synthesis and breakdown (Compiled from Schonberg et al. 1981; Rodemann \& Goldberg, 1982; Allen et al. 1985; Lathrop et al. 1985; Harper et al. 1987; Roe et al. 1989; Austin \& Burgess 1991; Arnold et al. 1992; Carnac et al. 1992; Harper \& Buttery, 1992; McMillan et al. 1992; Blachowski et al. 1993; Cook et al. 1993; Noble et al. 1993; Blachowski et al. 1994b; Garcia-Martinez et al. 1994; Harper \& Buttery, 1995; Desler et al. 1996; Dodson et al. 1996; Doumit et al. 1996; Florini et al. 1996; Husmann et al. 1996)

\begin{tabular}{|c|c|c|c|c|}
\hline \multirow[b]{2}{*}{ Factor } & \multicolumn{2}{|c|}{ Precursor cell (myoblast or satellite cell) } & \multicolumn{2}{|c|}{ Differentiated muscle cell (myotube or myofibre) } \\
\hline & Proliferation & Differentiation & Protein synthesis & Protein breakdown \\
\hline Insulin & $\uparrow \rightarrow$ & $\uparrow$ & $\uparrow$ & $\downarrow$ \\
\hline IGF & $\uparrow$ & $\uparrow$ & $\uparrow$ & 1 \\
\hline GH & $\rightarrow$ & $\uparrow \rightarrow$ & $\rightarrow$ & $\stackrel{\downarrow}{\rightarrow}$ \\
\hline FGF & $\uparrow \rightarrow$ & $\downarrow$ & $\rightarrow$ & nd \\
\hline $\mathrm{EGF}$ and $\mathrm{TGF} \alpha$ & $\rightarrow$ & $\uparrow$ & $\uparrow$ & 1 \\
\hline TGF $\beta$ & $\downarrow \rightarrow \uparrow$ & $\downarrow$ & $\downarrow \uparrow$ & nd \\
\hline PDGF & $\uparrow \rightarrow$ & $\downarrow$ & nd & nd \\
\hline Dex & $\uparrow \rightarrow$ & $\rightarrow 1$ & $\uparrow \downarrow$ & $\uparrow$ \\
\hline T3 & $\rightarrow$ & $\uparrow \rightarrow$ & $\rightarrow$ & $\rightarrow$ \\
\hline Test & $\rightarrow$ & 1 & $\rightarrow$ & $\rightarrow$ \\
\hline$\beta$-adrenergic agonist & $\uparrow \rightarrow$ & $\uparrow \rightarrow$ & $\uparrow \rightarrow$ & $\downarrow \rightarrow$ \\
\hline LIF & $\uparrow$ & nd & nd & nd \\
\hline IL-6 & $\uparrow$ & nd & nd & nd \\
\hline RA & nd & $\uparrow$ & nd & nd \\
\hline LA & nd & $\uparrow$ & nd & nd \\
\hline CGRP & nd & $\uparrow$ & nd & nd \\
\hline TNF- $\alpha$ & nd & nd & nd & $\uparrow$ \\
\hline$P G E_{2}$ & nd & nd & $\rightarrow$ & $\uparrow$ \\
\hline $\mathrm{PGF}_{2 \alpha}$ & nd & nd & $\uparrow$ & $\rightarrow$ \\
\hline
\end{tabular}

IGF, insulin-like growth factors-I and -11 ; GH, growth hormone; FGF, fibroblast growth factor; EGF and TGF- $\alpha$, epidermal growth factor and transforming growth factor- $\alpha$ (same receptor); TGF- $\beta$, transforming growth factor- $\beta$; PDGF, platelet-derived growth factor; Dex, dexamethasone; T3, triiodothyronine; Test, testosterone; $\beta$-adrenergic agonist, clenbuterol, ractopamine or isoproterenol; LIF, leukaemia inhibitory factor; IL-6, interleukin-6; RA, retinoic acid; LA, linoleic acid; CGRP, calcitonin-gene-related peptide; TNF- $\alpha$, tumour necrosis factor- $\alpha ; P E_{2}$, prostaglandin $E_{2} ; P F_{2 x}$, prostaglandin $F_{2 x} ; \uparrow$, stimulates; $\downarrow$, inhibits; $\rightarrow$, no effect; nd, no data found. 
differentiation have been shown to be concentrationdependent, with optimal concentrations for stimulation of differentiation $(10-50 \mathrm{ng} / \mathrm{ml}$ for IGF-I) lower than those for stimulation of proliferation $(80-100 \mathrm{ng} / \mathrm{ml}$ for IGF-I; Florini et al. 1986).

Insulin has also been shown to increase both proliferation and differentiation of various types of muscle cell, but at supra-physiological concentrations, and this is accepted as reflecting the ability of insulin to bind to the IGF-1R. Binding of insulin either to its own receptor or the IGF-1R is consistent with the observation that protein-tyrosine kinase is involved in the regulation of myogenin expression (Hashimoto et al. 1995).

Epidermal growth factor (EGF) and related peptides all bind to a common receptor, and stimulate the growth of normal muscle cells (see Blachowski et al. 1993; Harper \& Buttery, 1995). EGF also enhances differentiation, as measured by specific activity of the marker enzyme creatine kinase (Harper \& Buttery, 1995). These responses are direct effects on the muscle cells themselves, as can be demonstrated in experiments with the L6 myoblast cell line, which lacks EGF receptors, and fails to show either growth or differentiation responses to EGF. The effects on differentiation cannot be restored by co-culture with normal sheep muscle fibroblasts, which are EGF responsive (Roe et al. 1989; JMM Harper and CM Chaffey, unpublished results).

The fibroblast growth factors (FGF; acidic and basic) have been shown to stimulate proliferation (Dodson $e t$ al. 1996), but to inhibit differentiation of muscle cells (Lathrop et al. 1985). Transforming growth factor (TGF)- $\beta$, which has many isoforms, has been shown to have variable effects on proliferation, dependent on whether serum or other growth factors are present in the culture medium (Cook et al. 1993), but it has been shown to consistently inhibit differentiation.

A variety of other hormones, growth factors and prostaglandins have also been found to affect muscle cell proliferation and/or differentiation, as summarized in Table 1 , but the only other factors not yet mentioned which may have implications with regards to nutritional control of myogenesis are the thyroid hormones and the glucocorticoids. Thyroid hormones have long been known to be important in muscle development, and particularly the control of fibre type (for review, see Dauncey \& Gilmour, 1996), but triiodothyronine has also been shown to increase MyoD-gene transcription and to induce earlier and faster terminal differentiation in $\mathrm{C} 2$ myoblasts (Carnac et al. 1992). Glucocorticoids appear to have few direct effects on muscle cell proliferation and differentiation, although there has been one report of the synthetic glucocorticoid dexamethasone inhibiting differentiation of L8 myoblasts (Schonberg et al. 1981). Dexamethasone, however, has been shown to consistently enhance the mitogenic effects of IGF-I (for review, see Harper \& Buttery, 1995; Dodson et al. 1996), via increases in the IGF-1R signalling pathway (Giorgino \& Smith, 1995).

A common feature of the effects of various growth factors and hormones on muscle cell proliferation and differentiation, and also the metabolic effects described later (p. 209), appears to be activation of polyamine synthesis via the enzyme ornithine decarboxylase ( $E C$ 4.1.1.17). Differentiation of L6 muscle cells is inhibited by $\alpha$-difluoromethylornithine (DFMO), an irreversible inhibitor of ornithine decarboxylase (Ewton et al. 1982), with the stimulatory effects of insulin and IGF-I on both proliferation and differentiation also shown to be inhibited, but not completely abolished, by DFMO (Ewton et al. 1984; Blachowski et al. 1994a). Similarly, the stimulatory effects of EGF, TGF- $\alpha$ and TGF- $\beta 1$ on L6 muscle protein synthesis are also inhibited by DFMO (Blachowski et al. 1994c). Thus, the polyamines may play some role in the signal-transduction mechanism for growth factors.

\section{Effects of growth factors and hormones on myofibre protein metabolism}

The increase in size of muscle fibres that takes place postnatally involves increases in protein deposition within the cells, and some of the factors known to influence cell proliferation and differentiation can also influence protein metabolism within the cells, as summarized in Table 1 . Thus, factors such as EGF, $\beta$-adrenergic agonists, insulin and the IGF have all been shown to increase protein synthesis and to decrease protein breakdown in cultured muscle cells, whereas growth hormone $(\mathrm{GH})$ was found to have no effect, and dexamethasone had variable effects on protein synthesis, but increased protein breakdown (for review, see Harper \& Buttery, 1992).

\section{Autocrine expression of growth factors and their receptors}

A great deal of work has been carried out investigating possible local production of the growth factors known to affect muscle cell proliferation and differentiation, with particular interest being the IGF, because of their positive effects on both growth and differentiation.

Relatively recently, Hill et al. (1984) demonstrated that peptide growth factors, which were immunologically and biologically similar to IGF-I (somatomedin-C), were released into the culture medium by cultured fetal rat myoblasts. However, conflicting results have been published on the changes in expression of the IGF-I gene during skeletal muscle differentiation. Increased IGF-I mRNA expression with differentiation has been described in the C2 muscle cell-line (Szebenyi \& Rotwein, 1991), but decreased IGF-I mRNA expression with differentiation were observed in the BC3H-1 cell-line (Rosenthal et al. 1991b). We (JM Brameld, N Imram, N Millard, J Li, RS Gilmour and PJ Buttery, unpublished results) have recently demonstrated very low levels of IGF-I expression in proliferating primary fetal sheep myoblasts and neonatal sheep satellite cells, with an increase being observed with differentiation, reaching a plateau at about the same stage as the intracellular creatine kinase concentrations. The transcripts of IGF-I were predominantly class 1 (initiated from the exon 1 promoter), with class 2 transcripts (those initiated from the exon 2 promoter) only seen in cultures with high levels of class 1 transcripts. This contrasts with the in vivo situation where only very low levels of both 
class 1 and 2 transcripts are seen in adult sheep muscle (Pell et al. 1993), which is presumably fully differentiated, but may reflect an effect of maturity and innervation of the muscle. It is worth noting that full differentiation of muscle cells in culture takes 2-3 weeks, if the myotubes can be maintained for that length of time. Higher levels of total IGF-I mRNA have previously been described in fetal sheep muscle at day 84 of gestation compared with day 134 of gestation and days 8 and 12 in neonatal sheep muscle (Dickson et al. 1991), and may reflect a decrease in IGF-I mRNA once the muscle cells are fully differentiated and innervated.

Similar increases in IGF-II mRNA with differentiation have been described in the $\mathrm{C} 2$ muscle cell line (Tollefsen $e t$ al. 1989; Florine et al. 1991b; Szebenyi \& Rotwein, 1991; Ernst et al. 1992; Rosen et al. 1993), and also in the L6A1 (Magri et al. 1994) and BC3H-1 (Rosenthal et al. 1991b; Brown et al. 1992) muscle cell lines. Preliminary studies at Nottingham (JM Brameld, N Millard, J Li, RS Gilmour and PJ Buttery, unpublished results) have shown high levels of IGF-II mRNA expression in proliferating fetal sheep myoblasts, with a decline in IGF-II mRNA with increased differentiation. In comparison, expression of IGF-II mRNA was low in proliferating sheep satellite cells, and increased with differentiation. A decrease in IGF-II expression has recently been described during differentiation of clonallypurified turkey satellite cells (Ernst et al. 1996). These discrepancies may reflect fundamental differences between fetal and adult-derived muscle cells and also between primary cultures and cell lines, especially as fetal myoblasts tend to differentiate faster and to a greater extent than satellite cells. Recent evidence indicating an important role for locally-produced IGF-II on muscle cell differentiation comes from both cell-culture and wholeanimal studies. Muscle cell lines that differentiate spontaneously without the need for inclusion of IGF in the culture medium have been shown to express IGF-II mRNA (Florini et al. 1991b), with differentiation of such cells being inhibited by blocking IGF-II expression with the use of an anti-sense oligonucleotide. It would appear, therefore, that spontaneous muscle cell differentiation may be dependent on autocrine IGF-II. Similarly, studies of the doublemuscle syndrome, a hereditary condition in which cattle possess almost $40 \%$ more muscle fibres at birth than do normal cattle, indicate that there is increased muscle cell hyperplasia. Increased growth factor activity in the serum of fetuses with double-muscle syndrome during early fetal development have been demonstrated (Gerrard \& Judge, 1993), along with a delay in the maximal local IGF-II mRNA expression (Gerrard \& Grant, 1994). This delay in IGF-II expression may result in a delay in muscle cell differentiation and, therefore, allow greater time for proliferation to occur.

Distinct biologically-active receptors for both IGF have been observed in cultured L6 cells (Beguinot et al. 1985), but the orders of binding activities of the IGF and insulin would suggest that their effects are predominantly via the IGF-1R. We (JM Brameld, N Imram, RS Gilmour and PJ Buttery, unpublished results) have recently observed no change in expression of IGF-1R mRNA during differentiation of fetal sheep myoblasts, which agrees with a previous study using the L6 muscle cell line (Ewton et al. 1988), but is different from the results obtained with the $\mathrm{BC} 3 \mathrm{H}-1$ muscle cell line (Rosenthal et al. 1991b), and turkey primary satellite cells (Minshall et al. 1990), where decreases in IGF-1R mRNA (Rosenthal et al. 1991b) and IGF-I binding (Minshall et al. 1990) were observed with differentiation. The latter studies would agree with suggestions that the IGF themselves decrease the expression of the IGF-1R during differentiation (Rosenthal et al. $1991 b$ ), thus down-regulating the receptor. A recent study demonstrated that IGF-1R gene expression is decreased by IGF-I and increased by FGF in $\mathrm{C} 2 \mathrm{C} 12$ and BC $3 \mathrm{H}-1$ muscle cells (Rosenthal et al. 1991a; Hernández-Sánchez et al. 1997), which would support the idea that IGF-1R decreases with differentiation, a process stimulated by IGF-I and inhibited by FGF.

The IGF-binding proteins (IGFBP) play a fundamental role in modifying IGF bioactivity by a number of possible mechanisms, including protection against proteolytic degradation, targeting IGF in serum to specific tissues and regulating local IGF availability to receptors. It has also been suggested recently that the IGFBP themselves may bind to cell surfaces and have effects via IGF-independent mechanisms (see Mohan \& Baylink, 1996). At least five of the IGFBP appear to be produced by muscle cells in culture, with IGFBP-2, $-3,-4,-5$ and -6 being found at varying levels in different muscle cell types. For instance, the C2 muscle cell line appears to only secrete IGFBP-5 (Tollefsen et al. 1989; James et al. 1993), as does the BC3H-1 cell line (McCusker \& Clemmons, 1994), whereas L6 cells secrete IGFBP-4, -5 and -6 (McCusker and Clemmons, 1994; Silverman et al. 1995), turkey satellite cells secrete IGFBP-2 (Ernst et al. 1996), and fetal pig myoblasts secrete IGFBP-2, $-3,-4$ and -5 (Hembree et al. 1996). Secretion and expression of IGFBP-2 has been shown to decrease with differentiation in both primary turkey satellite cells (Ernst et al. 1996) and C2C12 cells (Ernst et al. 1992). Secretion of IGFBP-4 and -6 increases with differentiation in L6E9 cells (Silverman et al. 1995), as does secretion of IGFBP-5 in C2 cells (James et al. 1993, 1996). The relative effects of these different binding proteins on the processes of differentiation are still at an early stage, but enhancement of IGFBP-5 production via sense transfection methods results in a decrease in differentiation of $\mathrm{C} 2$ cells, whereas transfection of the anti-sense construct for IGFBP-5 results in decreased secretion of IGFBP-5 and the cells differentiate prematurely and to a greater extent (James et al. 1996). The inhibition of differentiation by high levels of IGFBP-5 secretion could be overcome by the addition of exogenous IGF. Similarly, recombinant IGFBP-6 has been shown to inhibit the IGF-II-induced differentiation of L6A1 cells in a dose-dependent manner, with no effect on IGF-I-induced differentiation (Bach et al. 1994, 1995). However, IGFBP produced by L6E9 cells (IGFBP-4 and -6) do inhibit IGF-Iinduced differentiation, with the suggestion being that, as IGFBP-6 has a low affinity for IGF-I, then the inhibitory effect is mediated by IGFBP-4 (Silverman et al. 1995). We (XF Guan, JM Brameld, JMM Harper and PJ Buttery, unpublished results) have recently demonstrated differences in IGFBP secreted by clonally-purified sheep muscle 
cells, derived from both myoblasts and satellite cells, which were classed as strongly fusion positive, weakly fusion positive or fusion negative. There was an increase in production of both IGFBP-3 (doublet at 39 and $43 \mathrm{kDa}$ ) and IGFBP-2 and -5 (28-34 kDa) with increased fusion, with the lower-molecular-weight binding proteins $(24 \mathrm{kDa})$, thought to be IGFBP-4, decreasing with increased fusion. This pattern of secreted binding proteins is very similar to that observed for fetal pig myoblasts and fibroblasts (Hembree et al. 1996), where myoblasts produced more IGFBP-3 and less IGFBP-4 than purified fibroblasts.

Other growth factors and receptors shown to be expressed by muscle cells include acidic and basic FGF and members of the TGF- $\beta$ superfamily, all of which inhibit muscle cell differentiation. Expression of acidic and basic FGF has been demonstrated in murine and rat skeletal muscle, and also in murine-derived sol8 and rat-derived L6 muscle cell lines, with expression of both genes being down-regulated during differentiation of both cell lines (Moore et al. 1991). There was also an associated decrease in FGF-receptor mRNA, and this coordinated downregulation was suggested as one possible mechanism whereby FGF may exert an autocrine effect on differentiation, as FGF inhibit muscle cell differentiation (see p. 209), myogenin-gene expression (Brunetti \& Goldfine, 1990) and also IGF-II-gene expression (Rosenthal et al. 1991a), whilst increasing IGF-1R abundance (Rosenthal et al. 1991a). Recently, a novel member of the TGF- $\beta$ superfamily, growth and differentiation factor-8 (GDF-8) has been identified (McPherron et al. 1997), and has been shown to be expressed specifically in developing and adult skeletal muscle. Knockouts of the GDF-8 gene result in dramatic increases in muscle mass, with individual muscles weighing two to three times more than those of wild-type animals, which would suggest that GDF-8 functions specifically as a negative regulator of skeletal-muscle growth, as does TGF- $\beta$. Decreases in both binding and action of TGF- $\beta$ with differentiation have been described in L6A1 cells (Ewton et al. 1988), similar to the decreases in FGF receptors.

\section{Effects of nutrients on myoblast proliferation and differentiation}

Muscle cell differentiation can be induced in most cell types by reduction of serum concentration in the culture medium. Differentiation has been shown to be dependent on other components of the cell culture medium, including the type of serum used (Doumit \& Merkel, 1992), the type of medium (Pinset \& Whalen, 1984; Dodson et al. 1990) and the substratum on which the cells are grown (Dodson $e t$ al. 1990). One report (Dodson et al. 1990) suggested that differentiation was increased in low-glucose compared with high-glucose Dulbecco's modified Eagle's medium. However, we have found no effect of low and high glucose concentrations on differentiation of primary fetal sheep myoblasts, as measured by changes in intracellular creatine kinase activity (JM Brameld, N Imram, J Li, RS Gilmour and PJ Buttery, unpublished results). There was also no effect of glucose concentration on expression of IGF-I or
IGF-IR genes. It has also been shown that the unsaturated fatty acid, linoleic acid, stimulates differentiation of rat satellite cells (Allen et al. 1985). The mechanism by which these nutrients affect myoblast differentiation could possibly be via effects on the GH-IGF axis, and in particular any locally-produced IGF-I, IGF-II, IGFBP and/or IGF-1R, all of which will alter IGF bioactivity. However, it is still uncertain whether primary myoblasts and/or myotubes possess functional GH-receptors and whether the IGF-I they produce is GH-dependent.

Studies involving the manipulation of specific nutrients in the media are lacking, and the published studies of direct nutritional effects on muscle cells in culture have involved mainly micronutrients. A lack of available $\mathrm{Zn}$ has been shown to inhibit $\mathrm{C} 2 \mathrm{C} 12$ myoblast differentiation and to decrease expression of both MyoD and myogenin mRNA (Petrie et al. 1996). Similarly, a lack of Ca can also inhibit muscle cell fusion (Merlie \& Gros, 1976; Morris et al. 1976), although effects on differentiated protein production appear to be concentration dependent (Morris et al. 1976). The effects of Ca may be related to the increase in the level of milli-calpain ( $E C$ 3.4.22.17), the Ca-dependent proteinase requiring millimolar concentrations of $\mathrm{Ca}$, seen during differentiation of fetal chicken myoblasts (Kwak et al. 1993). This increase in milli-calpain correlated with the elevated cleavage of filamin which occurs during the fusion process, and, therefore, may play an important role in the cytoskeletal reorganization required for myoblast fusion. This would also agree with the report that IGF-I, which stimulates differentiation, also increases milli-calpain mRNA concentrations (Hong \& Forsberg, 1994), although this observation was made in already-differentiated rat L8 myotubes. Retinoic acid, the vitamin A derivative, has also been shown to induce myogenic differentiation and myogenin synthesis in the rat Rhabdomyosarcoma cell line BA-Han-1C (Arnold et al. 1992). The effects of retinoids are mediated through two receptor subtypes, i.e. the retinoic acid receptors and the retinoid $X$ receptors, and expression of retinoic acid receptor mRNA has been shown to be repressed during $\mathrm{C} 2 \mathrm{C} 12$ myoblast differentiation, while retinoid $\mathrm{X}$ receptor mRNA was induced (Downes et al. 1994).

Growth and differentiation of muscle is profoundly affected by paracrine factors secreted by neighbouring cell types. Quinn et al. (1990) reported that the growth of normal myoblasts was enhanced markedly by factors secreted by muscle fibroblasts. Factors produced by the muscle itself will also affect the final cellular composition of the tissue. For example, we (JMM Harper and PJ Buttery, unpublished results) have demonstrated the existence of a low-molecular-weight mitogen produced by cultured satellite cells which enhances the growth of pre-adipocytes, with its action found to be additive to that of IGF-I.

\section{Whole-animal studies}

\section{Effects on muscle fibre number}

Evidence for effects of nutrition on muscle cell proliferation and differentiation comes from work in whole animals, 
with rates of fetal growth in the pig found to be very much dependent on maternal nutrition and the supply of maternal nutrients to the fetus. For example, a reduction in the uterine blood supply can lead to runting, with runted pigs being born with fewer muscle fibres (Powell \& Aberle, 1981), and consequently they never achieve the same mature size as their adequately-nourished siblings. Increasing maternal feed during pregnancy in pigs, especially during the period immediately before muscle fibre hyperplasia (between days 25 and 50 of gestation), has been shown to increase the average total number of muscle fibres and the secondary: primary fibres in the progeny at birth (Dwyer et al. 1994), with postnatal growth rate also being increased in these progeny. The increase in secondary : primary fibres was shown to be due to increased numbers of secondary fibres, with previous pig studies having shown correlations between growth rate and secondary: primary fibres (Dwyer et al. 1993). This suggests that early nutrition is crucial for the proliferation of presumptive secondary myoblasts, creating a greater potential for secondary-fibre formation. However, this approach cannot be used to increase fibre number in adequately-fed fetuses, rather it demonstrates the importance of adequate maternal nutrition during pregnancy. Whether these are direct effects or indirect effects mediated via the various metabolic hormones controlled by nutrient intake is yet to be established. Similar increases in muscle fibre number have been observed in progeny from sows injected with GH during pregnancy, but only when $\mathrm{GH}$ was administered in early (10-24d) gestation (Rehfeldt et al. 1993).

In utero exposure to $\beta$-adrenergic agonists has been reported to have variable effects on pre- and postnatal muscle growth. Maltin et al. (1990) demonstrated that exposure to clenbuterol in utero and during lactation decreased postnatal muscle growth in the hindlimbs of rat progeny. In contrast, Kim et al. (1994) reported that treatment of pregnant sows with salbutamol during either the first or second trimesters of pregnancy resulted in increased longissimus muscle area in the carcasses of the progeny at slaughter ( $160 \mathrm{~d}$ of age). Shackelford et al. (1995) fed pregnant ewes with a diet containing 0 or $2 \mathrm{mg}$ $\mathrm{L}_{64969}$ (Merck, Sharp \& Dohme, Rahway, NJ, USA; $\beta$ adrenergic agonist) $/ \mathrm{kg}$ between days 25 and 95 of gestation but observed no difference in the carcass or muscle weights of the progeny, either at birth or at any stage in the growth cycle. Heart weights, however, were increased ( $>20 \%$ at birth; Shackelford et al. 1995) by in utero exposure to the $\beta$-adrenergic agonist, which was taken as evidence that the $\beta$-adrenergic agonist must have crossed the placenta and affected lamb development. The lack of effect of in utero exposure to $\beta$-adrenergic agonist on muscle weight in either neonatal or market-weight lambs in the study of Shackelford et al. (1995) was attributed to the fact that fibre number was not increased by the $\beta$-adrenergic agonist, suggesting that myoblast proliferation and differentiation was unaffected by the drug. In the study of Maltin et al. (1990), a reduction in secondary:primary fibres was observed in the hindlimb muscles of rat fetuses exposed to clenbuterol in utero. This was due to a reduction in the number of secondary fibres but not primary muscle fibres.
This is consistent with the effects seen in pigs undernourished in utero (Dwyer et al. 1994). Total muscle DNA content was also reduced in these animals. In rats exposed to clenbuterol from day 10 of gestation and throughout lactation, total fibre number was reduced in the soleus muscle but there was an increase in fibre cross-sectional area, particularly in the type II fibres, and altered proportions of the different fibre types (Maltin et al. 1990). Fibre type was not altered in the muscles of the lambs exposed to $\beta$-adrenergic agonist (Shackelford et al. 1995), but Kim et al. (1994) suggested that in utero exposure to salbutamol increased the proportion of type I fibres in the semitendinosus muscle of pigs compared with untreated controls, in agreement with the results of Maltin et al. (1990). Differences between these studies may be related to the timing of $\beta$-adrenergic agonist administration, as was demonstrated for $\mathrm{GH}$ administration in pigs (Rehfeldt et al. 1993). The negative effect of $\beta$-adrenergic agonist on fetal muscle development in the study of Maltin et al. (1990) was attributed to nutrient restriction to the fetus due to the repartitioning action of the agonist in diverting nutrients towards the mother, as skeletal muscle hypertrophy was observed in both pregnant and lactating dams receiving the clenbuterol-supplemented diet. However, the possibility that clenbuterol has a direct effect on myoblast proliferation and/or differentiation could not be excluded.

Interestingly, in the study of Shackelford et al. (1995) it was noted that total fibre number in the semitendinosus muscle was higher for wethers than for ewes at market weight. A similar trend was observed in the psoas major muscle. This suggests that testosterone influences myoblast proliferation and/or differentiation. Longissimus muscle DNA concentration has been reported to be higher in bulls than in steers (Morgan et al. 1993), indicating that greater satellite-cell proliferation may occur in intact males and in animals treated with testosterone, where muscle mass and DNA content have been shown to be increased (Grigsby $e t$ al. 1976). It has been suggested that the anabolic steroid trenbolone acetate, a testosterone analogue, may increase skeletal muscle hypertrophy by enhancing the proliferation and differentiation of satellite cells by increasing the sensitivity of these cells to growth factors such as FGF and IGF-I (Thompson et al. 1989).

\section{Effects on muscle fibre hypertrophy}

In postnatal life, increases in muscle size are due to hypertrophy rather than hyperplasia as muscle fibre number does not increase significantly after birth. Muscle DNA content continues to increase throughout the growing phase due to satellite-cell proliferation, differentiation and fusion with existing muscle fibres. This is accompanied by increased protein deposition. The cessation of DNA accretion occurs abruptly as the animal approaches its mature size and precedes the decline in protein accretion. Muscle protein accretion is the net balance between the relative rates of muscle protein synthesis and degradation, and changes in either can result in increased muscle mass. This has been the basis of several growth promoters which have been used to increase muscle mass in farm livestock. 
The anabolic growth promotors, although no longer available for commercial use in the UK, have been shown to effectively increase muscle mass through hypertrophy. The mode of action of these agents differs depending on the compound; testosterone increases both protein synthesis and degradation rates, with a greater effect on the former (Martinez et al. 1984), while trenbolone acetate increases muscle mass predominantly by reducing protein degradation, with a lesser effect on protein synthesis (Vernon \& Buttery, 1976). The mode of action of oestradiol is believed to involve enhancement of endogenous GH secretion (Gopinath \& Kitts, 1984; Breier et al. 1988) although measurable increases in protein synthetic rate are not always observed in treated animals (Dawson et al. 1991). The response to anabolic agents, however, is clearly dependent on nutritional status (Gill et al. 1987).

Treatment of animals with exogenous GH has been clearly shown to increase fractional rates of protein synthesis and degradation in skeletal muscle, the increase in synthesis exceeding the increase in degradation resulting in protein accretion (Pell \& Bates, 1987; Eisemann et al. 1989). Total muscle RNA concentration is increased in GH-treated muscles suggesting increased protein synthetic capacity rather than increased efficiency of protein synthesis (Pell \& Bates, 1987).

Treatment of growing animals with other exogenous agents, such as $\beta$-adrenergic agonists, also results in increased muscle mass. The muscle hypertrophy exhibited is believed to occur through increased fibre diameter, with no proliferation of satellite cells. Indeed, muscle DNA concentration ( $\mu \mathrm{g} / \mathrm{g}$ protein) is sometimes less in treated muscles than in control muscles (Kim et al. 1987). The predominant mechanism of action of these agents is thus believed to be a reduction in protein degradation, although protein synthesis has also been shown to be stimulated in some studies (Dawson et al. 1991). This is supported by the observation that translational efficiency (i.e. the amount of protein synthesized per unit RNA) is increased by $\beta$ adrenergic agonists (Maltin et al. 1992). All muscles do not respond equally to treatment with $\beta$-adrenergic agonists (Dawson et al. 1991) and this is probably related to different fibre-type content of different muscles. The crosssectional area of type II (fast-contracting, mixed glycolytic-oxidative) fibres tends to be increased more consistently than type I (slow contracting, oxidative) fibres (see Yang \& McElligott, 1989). There also appears to be a change in proportions of fibre types in muscles of treated animals following long-term administration of these agents, with a shift towards fibres with increased anaerobic metabolism (Maltin et al. 1986; Zeman et al. 1988). These changes in fibre diameter and metabolism, along with the reduced protein degradation, are believed to contribute to the reduced tenderness of $\beta$-adrenergic-agonist-treated meat.

In sheep, an autosomal dominant gene (callipyge) has been identified on chromosome 18 which is associated with extreme muscling. The effect of this gene is not consistent among all skeletal muscles. The leg and loin muscles all exhibit hypertrophy (18-42\%), but certain shoulder muscles (e.g. supraspinatus and infraspinatus) are unaffected (Koohmaraie et al. 1995). The leg and loin muscle hypertrophy exhibited in sheep expressing the callipyge gene is similar to that seen in the double-muscle syndrome in cattle, but whereas the double-muscle syndrome is apparent at birth and often results in dystocia, the sheep condition does not manifest itself until several weeks after birth. This indicates that the mechanism giving rise to these conditions varies. The double-muscle syndrome is characterized by increased muscle fibre number which occurs as a result of faster and more prolonged hyperplasia during prenatal growth and development (Gerrard \& Judge, 1993). The callipyge condition is associated with increased muscle DNA content indicating greater satellite-cell proliferation, and increased RNA content suggesting greater capacity for protein synthesis (Koohmaraie et al. 1995). This condition is thus due to increased hypertrophy rather than hyperplasia. Protein degradation, however, is also significantly reduced in these animals, contributing to the increased muscle mass but also reducing meat tenderness. Changes in fibre type are also apparent, with an increase in the area of the type II fibres and a reduction or no change in the size of the red type I fibres. These changes resulted in sheep with the callipyge gene having $48-62 \%$ greater total muscle fibre areas compared with normal lambs (Koohmaraie $e t$ al. 1995). The proportion of type II fibres is also increased. These effects on muscle fibre area and the proportion of fibre types are similar to those often seen in $\beta$-adrenergicagonist-treated muscles (Yang \& McElligott, 1989) as are the changes in protein synthesis and degradation and meat tenderness.

Undernutrition can have important influences on postnatal growth, as well as in utero, if it occurs during critical stages of development. This was demonstrated in chickens, hatched and raised normally but starved for $48 \mathrm{~h}$ between 7 and $9 \mathrm{~d}$ of age and then subsequently refed normally until $27 \mathrm{~d}$ of age (Moss, 1968). Starvation decreased total muscle weight and the weight per nucleus, but the total number of nuclei remained constant. During refeeding muscle weights increased, but remained lower at $27 \mathrm{~d}$ of age than those of non-starved birds. Muscle nuclei number also remained lower in the starved birds. The muscle weight per nucleus, however, was constant in both groups of birds, suggesting that a brief period of starvation during the rapid growth phase reduced satellite-cell proliferation and, thus, DNA accumulation in the muscles which subsequently restricted postnatal protein accretion.

The proposed mechanisms for the effects of nutritional and hormonal manipulations on postnatal growth, and in particular the GH-IGF axis, have recently been reviewed (Straus, 1994; Brameld, 1997) and, therefore, will not be duplicated here. However, the evidence from studies in whole animals and cultured hepatocytes would seem to suggest that both the protein and energy constituents of a diet have direct effects on expression of growth-regulatory genes. Thus, increasing the energy available for growth, and therefore growth rate, via changes in dietary intake and environmental temperature of growing pigs, results in an increase in both GH receptor and IGF-I expression in liver, but a decrease in both $\mathrm{GH}$ receptor and IGF-I expression in Longissimus dorsi muscle (Dauncey et al. 1994; Weller et al. 1994). Similarly, increasing growth rate via increased dietary protein intake in GH-treated pigs also results in an increase in both GH receptor and IGF-I expression in liver, 
but a decrease in $\mathrm{GH}$ receptor expression in both $L$. dorsi and semitendinosus muscles, with no effect of dietary. protein on skeletal muscle IGF-I expression (Brameld $e t$ al. 1996). Thus, only energy appears to alter IGF-I expression in muscle, but there are tissue-specific effects of both energy and protein on GH receptor expression, with the effects on muscle being the opposite of those seen in liver. A lack of glucose in the culture medium reduces expression of the GH-receptor gene by cultured pig hepatocytes and, therefore, reduces the effects of GH on IGF-I expression (JM Brameld, RS Gilmour, and PJ Buttery, unpublished results). Similarly, a lack of certain essential amino acids in the culture medium reduces the effects of GH on IGF-I expression by cultured pig hepatocytes, although the mechanism appears to be slightly different from that of glucose (JM Brameld, RS Gilmour and PJ Buttery, unpublished results).

\section{Conclusions}

The control of muscle cell growth and differentiation is obviously under very tight multifactorial control, involving various growth factors, metabolic and steroid hormones and nutrients. There is a lack of studies on normal primary or secondary muscle cells as opposed to continuous cell lines, which by definition may have altered functions and control mechanisms. There is also a lack of studies on the effects of nutrients, including classical nutrients (e.g. glucose, amino acids) and the macro- and micronutrients, such as minerals and vitamins, which comprise the cell culture medium. These nutritional factors may elicit their effects via changes in the local production of growth factors or changes in growth factor activity.

\section{Acknowledgement}

The authors gratefully acknowledge the financial support of the BBSRC for much of this research.

\section{References}

Allen RE, Luiten LS \& Dodson MV (1985) Effect of insulin and linoleic acid on satellite cell differentiation. Journal of Animal Science 60, 1571-1579.

Arnold HH, Gerharz CD, Gabbert HE \& Salminen A (1992) Retinoic acid induces myogenin synthesis and myogenic differentiation in the rat rhabdomyosarcoma cell line BAHan-1C. Journal of Cell Biology 118, 877-887.

Austin L \& Burgess AW (1991) Stimulation of myoblast proliferation in culture by leukaemia inhibitory factor and other cytokines. Journal of Neurological Sciences 101, 193197.

Bach LA, Hsieh S, Brown AL \& Rechler MM (1994) Recombinant human insulin-like growth factor (IGF)-binding protein-6 inhibits IGF-II-induced differentiation of L6A1 myoblasts. Endocrinology 135, 2168-2176.

Bach LA, Salemi R \& Leeding KS (1995) Roles of insulin-like growth factor (IGF) receptors and IGF-binding proteins in IGFII-induced proliferation and differentiation of L6A1 rat myoblasts. Endocrinology 136, 5061-5069.

Beguinot F, Kahn CR, Moses AC \& Smith RJ (1985) Distinct biologically active receptors for insulin, insulin-like growth factor I, and insulin-like growth factor II in cultured skeletal muscle cells. Journal of Biological Chemistry 260, 1589215898.

Blachowski S, Buttery PJ, Brameld J, Charlton D \& Motyl T (1994a) Inhibition of proliferation and differentiation of fetal sheep myoblasts by an inhibitor of ornithine decarboxylase DFMO. Proceedings of the Society of Nutrition Physiology 3 291.

Blachowski S, Charlton D, Brameld J, Buttery PJ \& Motyl T (1994b) Comparison of metabolic effects of EGF, IGF-I, IGFII, and insulin in culture of fetal sheep myoblasts and fetal sheep fibroblasts. In: The Developing of Digestive and Metabolic Processes in New Bom and Growing Ruminants. Proceedings of the Satellite Symposium to the VIII International Symposium on Ruminant Physiology, Warsaw, Poland, pp. 6970 [W Barej, R Zabielski and P Ostaszewski, editors]. Warsaw: Fundacje Rozwoj SGGW.

Blachowski S, Motyl T, Grzelkowska K, Kasterk M, Orzechowski A \& Interewicz B (1994c) Involvement of polyamines in epidermal growth factor (EGF), transforming growth factor (TGF) $\alpha$ and $-\beta 1$ action on culture of L6 and fetal bovine myoblasts. International Journal of Biochemistry 26, 891-897.

Blachowski S, Motyl T, Orzechowski A, Grzelkowska K \& Interewicz B (1993) Comparison of metabolic effects of EGF, TGF- $\alpha$ and TGF- $\beta 1$ in primary culture of fetal bovine myoblasts and rat L6 myoblasts. International Journal of Biochemistry 25, 1571-1577.

Brameld JM (1997) Molecular mechanisms involved in the nutritional and hormonal regulation of growth in pigs. Proceedings of the Nutrition Society (In the Press).

Brameld JM, Atkinson JL, Saunders JC, Pell JM, Buttery PJ \& Gilmour RS (1996) Effects of growth hormone administration and dietary protein intake on insulin-like growth factor-I (IGFI) and growth hormone receptor (GHR) mRNA expression in porcine liver, skeletal muscle and adipose tissue. Journal of Animal Science 74, 1832-1841.

Breier BH, Gluckman PD \& Bass JJ (1988) Influence of nutritional status and oestradiol- $17 \beta$ on plasma growth hormone, insulin-like growth factors-I and -II and the response to exogenous growth hormone in young steers. Journal of Endocrinology 118, 243-250.

Brunetti A \& Goldfine ID (1990) Role of myogenin in myoblast differentiation and its regulation by fibroblast growth factor. Journal of Biological Chemistry 265, 5960-5963.

Brown EJ, Hsiao D \& Rosenthal SM (1992) Induction and peak gene expression of insulin-like growth factor II follow that of myogenin during differentiation of $\mathrm{BC} 3 \mathrm{H}-1$ muscle cells. Biochemical and Biophysical Research Communications 183, 1084-1089.

Carnac G, Albagli-Curiel O, Vandromme M, Pinset C, Montarras D, Laudet V \& Bonnieu A (1992) 3,5,3'-Triiodothyronine positively regulates both MyoD1 gene transcription and terminal differentiation in $\mathrm{C} 2$ myoblasts. Molecular Endocrinology 6, 1185-1194.

Cook DR, Doumit ME \& Merkel RA (1993) Transforming growth factor-beta, basic fibroblast growth factor, and platelet-derived growth factor-BB interact to affect proliferation of clonally derived porcine satellite cells. Journal of Cellular Physiology 157, 307-312.

Dauncey MJ, Burton KA, White P, Harrison AP, Gilmour RS, Duchamp C \& Cattaneo D (1994) Nutritional regulation of growth hormone receptor gene expression. FASEB Journal 8, 81-88.

Dauncey MJ \& Gilmour RS (1996) Regulatory factors in the control of muscle development. Proceedings of the Nutrition Society 55, 543-559.

Dawson JM, Buttery PJ, Lammiman MJ, Soar JB, Essex CP, Gill M \& Beever DE (1991) Nutritional and endocrinological 
manipulation of lean deposition in forage-fed steers. British Journal of Nutrition 66, 171-185.

Desler MM, Jones SJ, Smith CW \& Woods TL (1996) Effects of dexamethasone and anabolic agents on proliferation and protein synthesis and degradation in $\mathrm{C} 2 \mathrm{C} 12$ myogenic cells. Journal of Animal Science 74, 1265-1273.

Dickson MC, Saunders JC \& Gilmour RS (1991) The ovine insulin-like growth factor-I gene: characterization, expression and identification of a putative promoter. Journal of Molecular Endocrinology 6, 17-31.

Dodson MV, McFarland DC, Grant AL, Doumit ME \& Velleman SG (1996) Extrinsic regulation of domestic animal-derived satellite cells. Domestic Animal Endocrinology 13, 107-126.

Dodson MV, Mathison BA \& Mathison BD (1990) Effects of medium and substratum on ovine satellite cell attachment, proliferation and differentiation in vitro. Cell Differentiation and Development 29, 59-66.

Doumit ME, Cook DR \& Merkel RA (1996) Testosterone upregulates androgen receptors and decreases differentiation of porcine myogenic satellite cells in vitro. Endocrinology 137, 1385-1394.

Doumit ME \& Merkel RA (1992) Conditions for isolation and culture of porcine myogenic satellite cells. Tissue and Cell 24, 253-262.

Downes M, Mynett-Johnson L \& Muscat GEO (1994) The retinoic acid and retinoid $X$ receptors are differentially expressed during myoblast differentiation. Endocrinology 134, 2658-2661.

Duclos MJ, Wilkie RS \& Goddard C (1991) Stimulation of DNA synthesis in chicken muscle satellite cells by insulin and insulin-like growth factors: evidence for exclusive mediation by a type-I insulin-like growth factor receptor. Journal of Endocrinology 128, 35-42.

Dwyer CM, Fletcher JM \& Stickland NC (1993) Muscle cellularity and postnatal growth in the pig. Journal of Animal Science 71, 3339-3343.

Dwyer CM, Stickland NC \& Fletcher JM (1994) The influence of maternal nutrition on muscle fiber number development in the porcine fetus and on subsequent postnatal growth. Journal of Animal Science 72, 911-917.

Eisemann JH, Hammond AC \& Rumsey TS (1989) Tissue protein synthesis and nucleic acid concentrations in steers treated with somatotropin. British Journal of Nutrition 62, 657-671.

Emst CW, McCusker RH \& White ME (1992) Gene expression and secretion of insulin-like growth factor-binding proteins during myoblast differentiation. Endocrinology 130, 607-615.

Emst CW, McFarland DC \& White ME (1996) Expression of insulin-like growth factor II (IGF-II), IGF binding protein- 2 and myogenin during differentiation of myogenic satellite cells derived from the turkey. Differentiation 61, 25-33.

Ewton DZ, Erwin BG, Pegg AE \& Florini JR (1982) Inhibition of L6 myoblasts differentiation by DFMO and its reversal by polyamines. Journal of Cell Biology 95, 366a.

Ewton DZ, Erwin BG, Pegg AE \& Florini JR (1984) The role of polyamines in somatomedin-stimulated differentiation of L6 myoblasts. Journal of Cellular Physiology 120, 263-270.

Ewton DZ, Roof SL, Magri KA, McWade FJ \& Florini JR (1994) IGF-II is more active than IGF-I in stimulating L6A1 myogenesis: Greater mitogenic actions of IGF-I delay differentiation. Journal of Cellular Physiology 16, 277-284.

Ewton DZ, Spizz G, Olson EN \& Florini JR (1988) Decrease in transforming growth factor- $\beta$ binding and action during differentiation in muscle cells. Journal of Biological Chemistry 263, 4029-4032.

Florini JR, Ewton DZ \& Coolican SA (1996) Growth hormone and the insulin-like growth factor system in myogenesis. Endocrine Reviews 17, 481-517.
Florini JR, Ewton DZ, Falen SL \& Van Wyk JJ (1986) Biphasic concentration dependency of stimulation of myoblast differentiation by somatomedins. American Journal of Physiology 250, C771-C778.

Florini JR, Ewton DZ \& Roof SL (1991a) Insulin-like growth factor-I stimulates terminal myogenic differentiation by induction of myogenin gene expression. Molecular Endocrinology 5, 718-724.

Florini JR, Magri KA, Ewton DZ, James PL, Grindstaff K \& Rotwein PS (1991b) "Spontaneous" differentiation of skeletal myoblasts is dependent upon autocrine secretion of insulin-like growth factor-II. Journal of Biological Chemistry 266, 15917 15923.

Garcia-Martinez C, Llovera M, Agell N, López-Soriano FJ \& Argilés JM (1994) Ubiquitin gene expression in skeletal muscle is increased by tumour necrosis factor- $\alpha$. Biochemical and Biophysical Research Communications 201, 682-686.

Gerrard DE \& Grant AL (1994) Insulin-like growth factor-II expression in developing skeletal muscle of double muscled and normal cattle. Domestic Animal Endocrinology 11, 339-347.

Gerrard DE \& Judge MD (1993) Induction of myoblast proliferation in L6 myoblast cultures by fetal serum of double muscled and normal cattle. Journal of Animal Science 71, 1464-1470.

Gill M, Beever DE, Buttery PJ, England P, Gibb MJ \& Baker RD (1987) The effect of oestradiol-17 $\beta$ implantation on the response in voluntary intake, live-weight gain and body composition, to fishmeal supplementation of silage offered to growing calves. Journal of Agricultural Science, Cambridge 108, 9-16.

Giorgino F \& Smith RJ (1995) Dexamethasone enhances insulinlike growth factor-I effects on skeletal muscle cell proliferation: Role of specific intracellular signalling pathways. Journal of Clinical Investigation 96, 1473-1483.

Gopinath R \& Kitts WD (1984) Growth hormone secretion and clearance rate in growing beef steers implanted with oestrogenic anabolic compounds. Growth 48, 499-514.

Grigsby JS, Bergen WG \& Merkel RA (1976) The effect of testosterone on skeletal muscle development and protein synthesis in rabbits. Growth 40, 303-316.

Harper JMM \& Buttery PJ (1992) Muscle cell growth. In The Control of Fat and Lean Deposition, pp. 27-58 [PJ Buttery, KN Boorman and DB Lindsay, editors]. Oxford: ButterworthHeinemann.

Harper JMM \& Buttery PJ (1995) Muscle cell growth. Meat Focus International 4, 323-329.

Harper JMM, Soar JB \& Buttery PJ (1987) Changes in protein metabolism of ovine primary muscle cultures on treatment with growth hormone, insulin, insulin-like growth factor I or epidermal growth factor. Journal of Endocrinology 112, $87-96$.

Hashimoto N, Ogashiwa M \& Iwashita S (1995) Role of tyrosine kinase in the regulation of myogenin expression. European Journal of Biochemistry 227, 379-387.

Hembree JR, Pampusch MS, Yang F, Causey JL, Hathaway MR \& Dayton WR (1996) Cultured porcine myogenic cells produce insulin-like growth factor binding protein-3 (IGFBP-3) and transforming growth factor beta-1 stimulates IGFBP-3 production. Journal of Animal Science 74, 1530-1540.

Hernández-Sánchez C, Werner H, Roberts CT Jr, Woo EJ, Hum DW, Rosenthal SM \& LeRoith D (1997) Differential regulation of insulin-like growth factor-I (IGF-I) receptor gene expression by IGF-I and basic fibroblastic growth factor. Journal of Biological Chemistry 272, 4663-4670.

Hesketh JE \& Whitelaw PF (1992) The role of cellular oncogenes in myogenesis and muscle cell hypertrophy. International Journal of Biochemistry 24, 193-203. 
Hill DJ, Crace CJ, Fowler L, Holder AT \& Milner RDG (1984) Cultured fetal rat myoblasts release peptide growth factors which are immunologically and biologically similar to somatomedin. Journal of Cellular Physiology 119, 349-358.

Hong D-H \& Forsberg NE (1994) Effects of serum and insulinlike growth factor I on protein degradation and protease gene expression in rat L8 myotubes. Journal of Animal Science 72, 2279-2288.

Husmann I, Soulet L, Gautron J, Martelly I \& Barritault D (1996) Growth factors in skeletal muscle regeneration. Cytokine and Growth Factor Reviews 7, 249-258.

Ivarie $\mathbf{R}$ (1993) The myogenic regulatory factors and the early steps of muscle cell differentiation and growth. Journal of Animal Science 71 Suppl. 2, 23-32.

James PL, Jones SB, Busby WH Jr, Clemmons DR \& Rotwein P (1993) A highly conserved insulin-like growth factor-binding protein (IGFBP-5) is expressed during myoblast differentiation. Journal of Biological Chemistry 268, 22305-22312.

James PL, Stewart CEH \& Rotwein P (1996) Insulin-like growth factor binding protein-5 modulates muscle differentjation through an insulin-like growth factor-dependent mechanism. Journal of Cell Biology 133, 683-693.

Kim YS, Lee YB, \& Dalymple RH (1987) Effect of the repartitioning agent, cimaterol on growth, carcass and skeletal muscle characteristics in lambs. Journal of Animal Science $\mathbf{6 5}$, 1392-1399.

Kim YS, Sainz RD, Ferlazzo J \& Tulloh NM (1994) Effect of maternal administration of salbutamol to sows on post-natal growth and carcass characteristics in the progeny. Australian Journal of Agricultural Research 45, 271-278.

Koohmaraie M, Shackelford SD, Wheeler TL, Longergan SM \& Doumit ME (1995) A muscle hypertrophy condition in lamb (callipyge): characterization of effects on muscle growth and meat quality traits. Journal of Animal Science 73, 3596-3607.

Kwak KB, Chung SS, Kim O-M, Kang M-S, Ha DB \& Chung CH (1993) Increase in the level of m-calpain correlates with the elevated cleavage of filamin during myogenic differentiation of embryonic muscle cells. Biochimica et Biophysica Acta 1175, 243-249.

Lathrop B, Olson E \& Glaser L (1985) Control by fibroblast growth factor of differentiation in the $\mathrm{BC} 3 \mathrm{H} 1$ muscle cell line. Journal of Cell Biology 100, 1540-1547.

Ludolph DC \& Konieczny SF (1995) Transcription factor families: muscling in on the myogenic program. FASEB Journal 9, 1595-1604.

McCusker RH \& Clemmons DR (1994) Effects of cytokines on insulin-like growth factor-binding protein secretion by muscle cells in vitro. Endocrinology 134, 2095-2102.

McMillan DN, Noble BS \& Maltin CA (1992) The effect of the $\beta$ adrenergic agonist clenbuterol on growth and protein metabolism in rat muscle cell cultures. Journal of Animal Science 70, 3014-3023.

McPherron AC, Lawler AM \& Lee S-J (1997) Regulation of skeletal muscle mass in mice by a new TGF- $\beta$ superfamily member. Nature 387, 83-90.

Magri KA, Benedict MR, Ewton DZ \& Florini JR (1994) Negative feedback regulation of insulin-like growth factor-II gene expression in differentiating myoblasts in vitro. Endocrinology 135, 53-62.

Maltin CA, Delday MI \& Hay SM (1990) The effect of clenbuterol administration in utero and throughout lactation on pre- and post-natal muscle development in the rat. Growth, Development and Aging 54, 143-150.

Maltin CA, Delday MI \& Reeds PJ (1986) The effect of a growth promoting drug, clenbuterol, on fibre frequency and area in hind limb muscles from young rats. Bioscience Reports 6, 293299.
Maltin CA, Hay SM, McMillan DN \& Delday MI (1992) Tissue specific responses to clenbuterol: temporal changes in protein metabolism of striated muscle and visceral tissues from rats. Growth Regulation 2, 161-166.

Mangiacapra FJ, Roof SL, Ewton DZ \& Florini JR (1992) Paradoxical decrease in Myf-5 messenger RNA levels during induction of myogenic differentiation by insulin-like growth factors. Molecular Endocrinology 6, 2038-2044.

Martinez JA, Buttery PJ \& Pearson JT (1984) The mode of action of anabolic agents, the effects of testosterone on growth rates and muscle protein metabolism in female rats. British Journal of Nutrition 54, 515-521.

Merlie JP \& Gros F (1976) In vitro myogenesis: expression of muscle specific function in the absence of cell fusion. Experimental Cell Research 97, 406-412.

Minshall RD, McFarland DC \& Doumit ME (1990) Interaction of insulin-like growth factor I with turkey satellite cells and satellite cell-derived myotubes. Domestic Animal Endocrinology 7, 413-424.

Mohan S \& Baylink DJ (1996) Insulin-like growth factor (IGF)binding proteins in serum - Do they have additional roles besides modulating the endocrine IGF actions? Endocrinology 81, 3817-3820.

Montarras D, Chelly J, Bober E, Arnold H, Ott MO, Gros F \& Pinset C (1991) Developmental patterns in the expression of Myf5, MyoD, myogenin, and MRF4 during myogenesis. New Biologist 3, 592-600.

Moore JW, Dionne C, Jaye M \& Swain JL (1991) The mRNAs encoding acidic FGF, basic FGF and FGF receptor are coordinately downregulated during myogenic differentiation. Development 111, 741-748.

Morgan JB, Wheeler TL, Koohmaraie M, Crouse JD \& Savell JW (1993) Effect of castration on myofibrillar protein turnover, endogenous proteinase activities and muscle growth in bovine skeletal muscle. Journal of Animal Science 71, 408414.

Morris GE, Piper M \& Cole R (1976) Differential effects of calcium ion concentration on cell fusion, cell division and creatine kinase activity in muscle cell cultures. Experimental Cell Research 99, 106-114.

Moss FP (1968) The relationship between the dimensions of the fibres and the number of nuclei during restricted growth, regrowth and compensatory growth of skeletal muscle. American Journal of Anatomy 122, 565-569.

Noble BS, McMillan DN \& Maltin CA (1993) Calcitonin gene related peptide stimulates differentiation of neonatal rat myogenic cultures. Growth Regulation 3, 245-248.

Olson EN \& Klein WH (1994) bHLH factors in muscle development: dead lines and commitments, what to leave in and what to leave out. Genes and Development 8, 1-8.

Pell JM \& Bates PC (1987) Collagen and non-collagen protein turnover in skeletal muscle of growth hormone-treated lambs. Journal of Endocrinology 115, R1-R4.

Pell JM, Saunders JC \& Gilmour RS (1993) Differential regulation of transcription initiation from insulin-like growth factor-I (IGF-I) leader exons and of tissue IGF-I expression in response to changed growth hormone and nutritional status in sheep. Endocrinology 132, 1797-1807.

Petrie L, Buskin JN \& Chesters JK (1996) Zinc and the initiation of myoblast differentiation. Journal of Nutritional Biochemistry 7, 670-676.

Pinset C \& Whalen RG (1984) Manipulation of medium conditions and differentiation in the rat myogenic cell line L6. Developmental Biology 102, 269-277.

Powell SE \& Aberle ED (1981) Skeletal-muscle and adiposetissue cellularity in runt and normal birth-weight swine. Journal of Animal Science 52, 748-756. 
Quinn LS, Ong LD \& Roeder RA (1990) Paracrine control of myoblast proliferation and differentiation by fibroblasts. Developmental Biology 140, 8-19.

Rawls A \& Olson EN (1997) MyoD meets its maker. Cell 89, 5-8. Rehfeldt C, Fiedler I, Weikard R, Kanitz E \& Ender K (1993) It is possible to increase skeletal-muscle fiber number in utero. Bioscience Reports 13, 213-220.

Rodemann HP \& Goldberg AL (1982) Arachidonic acid, prostaglandin $E_{2}$ and $F_{2 x}$ influence rates of protein turnover in skeletal and cardiac muscle. Journal of Biological Chemistry 257, 1632-1638.

Roe JA, Harper JMM \& Buttery PJ (1989) Protein metabolism in ovine primary muscle cultures derived from satellite cells effects of selected peptide hormones and growth factors. Joumal of Endocrinology 122, 565-571.

Rosen KM, Wentworth BM, Rosenthal N \& Villa-Komaroff L (1993) Specific, temporally regulated expression of the insulinlike growth factor II gene during muscle cell differentiation. Endocrinology 133, 474-481.

Rosenthal SM, Brown EJ, Brunetti A \& Goldfine ID (1991a) Fibroblast growth factor inhibits insulin-like growth factor-II (IGF-II) gene expression and increases IGF-I receptor abundance in BC3H-1 muscle cells. Molecular Endocrinology, 5 678-684.

Rosenthal SM, Brunetti A, Brown EJ, Mamula PW \& Goldfine ID (1991b) Regulation of insulin-like growth factor (IGF) I receptor expression during muscle cell differentiation: Potential autocrine role of IGF-II. Journal of Clinical Investigation 87, 1212-1219.

Rudnicki MA, Schnegelsberg PNJ, Stead RH, Braun T, Arnold HH \& Jaenisch R (1993) MyoD or Myf-5 is required for the formation of skeletal muscle. Cell 75, 1351-1359.

Schonberg M, Smith TJ, Krichevsky A \& Bilezikian JP (1981) Glucocorticoids enhance glucose uptake and affect differentiation and beta-adrenergic responsiveness in muscle cell cultures. Cell Differentiation 10, 101-107.

Shackelford SD, Wheeler TL \& Koohmaraie M (1995) The effects of in utero exposure of lambs to a $\beta$-adrenergic agonist on prenatal and postnatal muscle growth, carcass cutability, and meat tenderness. Journal of Animal Science $\mathbf{7 3}$, 2986-2993.
Silverman LA, Cheng Z-Q, Hsiao D \& Rosenthal SM (1995) Skeletal muscle cell-derived insulin-like growth factor (IGF) binding proteins inhibit IGF-I-induced myogenesis in rat L6E9 cells. Endocrinology 136, 720-726.

Smith CK, Janney MJ \& Allen RE (1994) Temporal expression of myogenic regulatory genes during activation, proliferation, and differentiation of rat skeletal muscle satellite cells. Journal of Cellular Physiology 159, 379-385.

Straus DS (1994) Nutritional regulation of hormones and growth factors that control mammalian growth. FASEB Journal 8, 612.

Szebenyi G \& Rotwein P (1991) Insulin-like growth factors and their receptors in muscle development. In: Molecular Biology and Physiology of Insulin and Insulin-Like Growth Factors, pp. 289-295 [MK Raizada and D LeRoith, editors]. New York: Plenum Press.

Thompson SH, Boxhorn LK, Wong W \& Allen RE (1989) Trenbolone alters the responsiveness of skeletal muscle satellite cells to fibroblast growth factor and insulin-like growth factor I. Endocrinology 124, 2110-2117.

Tollefsen SE, Sadow JL \& Rotwein P (1989) Coordinate expression of insulin-like growth factor II and its receptor during muscle differentiation. Proceedings of the National Academy of Sciences USA 86, 1543-1547.

Vernon BG \& Buttery PJ (1976) Protein turnover in rats treated with trenbolone acetate. British Journal of Nutrition 36, 575579.

Weintraub H (1993) The MyoD family and myogenesis: Redundancy, networks, and thresholds. Cell 75, 1241-1244.

Weller PA, Dauncey MJ, Bates PC, Brameld JM, Buttery PJ \& Gilmour RS (1994). Regulation of porcine insulin-like growth factor-I and growth hormone receptor mRNA expression by energy status. American Journal of Physiology 266, E776E785.

Yang YT \& McElligott MA (1989) Multiple actions of $\beta$ adrenergic agonists on skeletal muscle and adipose tissue. Biochemical Journal 261, 1-10.

Zeman RJ, Ludemann R, Easton TG \& Etlinger JD (1988) Slow to fast alterations in skeletal muscle fibers caused by clenbuterol, a B2-receptor agonist. American Journal of Physiology 254, E726-E732. 